\title{
Engagement Levels of Foreign Teachers at Saint Nicholas School in Phitsanulok, Thailand
}

\author{
Ronnie L. Torres OMI
}

\begin{abstract}
Employee engagement is a multidimensional, complicated and frequently encountered challenge by companies and organizations. Engagement is not just an idea or a concept but a reality that happens in workplaces every day. HR departments have acknowledged that engagement is a great contributor to the success of the organization where employees who are engaged in their work contribute significantly to the creation of decent and pleasant working situation which consists of workforce who are ethical, responsible and goal-driven. Various authors and researchers have confirmed engagement as a boiling issue in workplaces as manifested in most articles regarding human resource management that frequently dealt with engagement as one of the top issues; although it was a new issue being studied in the academe where academic researchers focus mainly on expounding emotional concepts and its measurement, but not into gender differences. This study examined 21 foreign teachers' employee engagement levels in Saint Nicholas School in Phitsanulok, Thailand. As gender differences are assumed to be related to employee engagement, this study also delved into how men and women foreign teachers differ in their engagement levels in terms of basic needs, management support, belongingness, and opportunities for growth. The result was established and verified by computing the mean scores, standard deviation, and the use of T-Test to determine significant difference of employee engagement between genders. Comprehensive investigation of the data showed that foreign teachers are positively and generally engaged in their work. The study shows that there is no significant difference in the employee engagement among male and foreign teachers in all factors and questions - meaning, gender does not affect foreign teachers' employee engagement levels in Saint Nicholas School in Phitsanulok, Thailand. This paper offers opportunities to readers and future researchers to deeply investigate into the various factors, not only limited to gender, that affect employee engagement particularly of teachers in academic institutions.
\end{abstract}

Index Terms - employee engagement, gender and employee engagement, teacher engagement levels.

\section{INTRODUCTION}

Employee engagement is a multidimensional, complicated and frequently encountered challenge by companies and organizations. Engagement is not just an idea or a concept but a reality that happens in workplaces every day. HR departments have acknowledged that engagement is a great contributor to the success of the organization where employees who are engaged in their work contribute significantly to the creation of decent and pleasant working situation which consists of workforce that is ethical,

Ronnie L. Torres OMI, Deputy Director of Saint Nicholas School in Phitsanulok, North of Thailand. responsible and goal-driven. Various authors and researchers have confirmed engagement as a boiling issue in workplaces as manifested in most articles regarding human resource management that frequently dealt with engagement as one of the top issues; although it was a new issue being studied in the academe where academic researchers focus mainly on expounding emotional concepts and its measurement, but not into gender differences.

\section{A. Statement of Purpose}

This study aims to find out foreign teachers' employee engagement levels at Saint Nicholas School in Phitsanulok, Thailand. Gender is assumed to be related to employee engagement. Thus, gender will be explored in this study and how it affects employee engagement.

\section{B. Research Questions}

This research answered the following questions:

1. What is the employee engagement level of foreign teachers in Saint Nicholas School, Phitsanulok?

2. What engagement factors are the male foreign teachers most engaged in?

3. What engagement factors are the female foreign teachers most engaged in?

4. What engagement factors are the male foreign teachers least engaged in?

5. What engagement factors are the female foreign teachers least engaged in?

6. Is there any significant difference in the employee engagement among male and female foreign teachers in Saint Nicholas School, Phitsanulok?

\section{Hypothesis}

1. There is no significant difference in the employee engagement levels among male and female foreign teachers in Saint Nicholas School, Phitsanulok.

\section{REVIEW OF RELATED LITERATURE AND STUDIES}

\section{A. Employee Engagement}

Employee engagement is a great contributor to the success of the organization, where employees who are engaged in their work contribute significantly to the creation of decent and pleasant working situation which consists of the workforce who are ethical, responsible and goal-driven (Levinson, 2007). Vast literature had attempted to define this term but often come up with conflicting, if not inconsistent definition. 
Gallop Consulting Firm, who first used the term, defined employee engagement as "those who are involved in, enthusiastic about and committed to their work and the workplace" (Gallup Daily, 2017). Kahn (1990) as cited by Remo (2012), was the first academic researcher to use the term engagement in academics and defined employee engagement as the level of commitment and association of employees towards their organization. Kahn further elucidated that employee engaged themselves to work physiologically, psychologically and cognitively. Smith and Markwick, (2009) collated meanings and concepts given by different companies and arrived at this description: engagement is something given by employees like attachment and loyalty to the company by expending work time, finding ways to add value and use talents in their work, supporting organization's values and goals for the benefit of the organization.

Having said this, organizations must understand the differences on how employees express themselves in the workplace which in effect, increase motivation, profitability, productivity, safety, retention, and engagement level, while lack of association may offer the opposite (Sadhara and Patrick, 2011).

Reilly (2014) listed five strategies for organizations to adopt so that employees stay engaged in the organization, increase job satisfaction, productivity, and profitability, and retention, to name:

1. Focus on individual and organizational engagement. The change should happen at all workgroup levels and from individual to organizational levels. If and when individual employees are engaged, it creates a ripple that affects the whole organization. Every employee must be empowered so that they can perform at their best and make noteworthy transformation in their workplace.

2. Select the right managers. Managers who understand and own their organizational goals and objectives are likely to make a difference in the workplace. Effective managers understand their employees, look after their welfare, empower, listen to, recognize and put them at the right job.

3. Trained managers. According to Gallup as cited by Reilly (2014), why employees are engaged, less engaged or disengaged are because of their managers. This spells an organization's responsibility to train and provide professional development programs to their managers.

4. Define goals. Goals and objectives must be communicated at all levels of the workforce and make employees understand and own the goals thereby making these goals relevant and meaningful to them.

5. Use the right employee engagement survey. A problem can be solved with the right solution. In order to effectively identify the level of engagement of employees, organizations must use the right instrument and offer solutions that are measurable, attainable, realistic and time-bounded for any group at all levels or the organization.

\section{B. Variations of Employee Engagement}

Kahn (1990) and Sonnentag (2003) as cited by Smith and Markwick (2009) claimed that individual experience of engagement varies from one person to the other depending on their psychological and physiological individualities. Robinson et al., (2007) confirmed in his study that gender, age, cultural background, disability, and responsibility have differing effects on engagement. The same study also established that younger employee especially those who belong to Generation Y and beyond are less positive and the most disengaged members of the organization. In a survey made by BlessingWhite (2008), they concluded that employees born before the 1980s are more engaged while those born after are less engaged attributing to their lower leadership role in the organization. Another survey conducted by Roffey Park Institute in the UK (Boury, et al., 2013), reveals that younger managers are less engaged and less positive about their organization compared to that of advanced in age which less experience, differing values, generation gaps in the workplace may be a major contributing factor.

The individual character of the person is also strongly linked to employee engagement. There are persons who are really like to engage, participate and be in the limelight; while there are others who just like to be spectators. Organizations should find out these attitudes in their employees because these attitudes may greatly affect organization's performance in general.

Another element that is strongly connected to employee engagement is the standard of living prospects of employees. With the change in the landscape of the workplace, the organizations need to be flexible is a must. A lot of employees nowadays work in order to satisfy their desire for a particular lifestyle and what they consider is worth investing for themselves (Smith and Markwick, 2009).

Lastly, employee's roles being played and the number of years spent been in the organization also plays a very important role in engagement. A survey made by Perrin (2003) as cited by Smith and Markwick (2009) concluded that those who are holding higher positions in the organization tend to be more engaged while those on the staff level tend to be less engaged if not disengaged.

\section{Types of engagements}

The common concept that employees are the most important asset of any organization can only be correct if and when employees are engaged. Employees can be classified into three different types depending on the level of commitment (Front Line Leadership, 2018; ), to wit:

1. Engaged employees are those who put their all for their work and the organization. They are passionate, committed, innovative, creative and consistent in their performance goals of bringing the organization to the top. They exhibit a sense of ownership of their organization and at all times, work beyond what is expected of them (Vazirani, 2007).

2. Not engaged employees are those who work according to what is on their job description. They put their time, but not their dynamism and passion in 
their work (Reilly, 2014). They do not have a good working relationship with their colleagues and only consider their work as their bread and butter and nothing else.

3. Actively disengaged employees do not perform their job appropriately. They are inappropriate, angry, nosey and spread negativity within the workplace. These employees contribute insignificantly for the success of the organization; rather, they bring the organization into the bad light. But, these people stay longer in the organization by weeding out potential employees who will attain a higher position.

\section{Related Studies on Employee Engagement}

Engagement is a positive experience of an employee that made them stay in the organization (Levinson, 2007). In a research done by Blessing White (2008), 85\% of respondents who claimed to be engaged, expressed desire of staying in the organization; and $41 \%$ from the $85 \%$ engaged respondents expressed that they will stick with the organization should it experience tough times - an expression of organizational commitment and loyalty. Employee engagement is closely and positively linked to employee commitments which manifest their pledge of helping the organization achieve its goals and objectives through. Commitment is defined as the feeling of attachment of employees towards their organization (Sak, 2006). Employees think of leaving the company if they are not satisfied and engaged; however, engaged employees do not easily quit their job, but stay in the organization for a long time (Kumar and Swetha, 2011).

Munish and Agarwal's (2017) research called "Employee engagement and retention: A review of literature"reviewed 30 relevant research papers and literature that dealt with employee retention and engagement in order to identify and analyse critical factors that affect employee retention and engagement. The analysis of the research papers and literature found out that professional development, compensation benefits, autonomy, and healthy work environment contribute to effective and efficient employee engagement and retention. Four major elements were identified by the authors that significantly affect employee retention and engagement namely: healthy work environment, organizational reputation and organizational ethics; career advancement; professional development; and attractive fringe and rights benefits. The study also revealed that employee engagement is highly correlated with employee retention.

David and Pandey (2013) conductedtheir study called "A study of engagement at work: what drives employee engagement?" aimed at finding out what drives employee engagement at work. 107 Indian employees from the IT and the pharmaceutical sectors were the subject of the study. Fourteen (14) factors namely: growth opportunities within the organization, work life balance, supervisor-subordinate relationship, physical resources availability, rewards and recognition, clear policies and open communication, fair compensation policies, adequate training for skills up gradation, role clarity, and pride in working for the company were identified as dimensions of employee engagement. Of the fourteen (14) factors identified by the researchers to comprise the survey, three factors emerged as the major contributor of employee engagement in the workplace namely: satisfactory work environment, growth opportunities and job enrichment.

In a research conducted by Singh and Garrad (2017) for Mercer Singapore entitled "Singapore employee engagement Index: Insight to enhance workforce productivity", the authors studied more than 40,000 Singaporean employees from different business industries and jobs re employee engagement. In their research, it came out that Singapore remains struggling with engagement where $81 \%$ of Singaporean employees are proud of their companies; $80 \%$ were willing to go extra mile; and $73 \%$ were satisfied with the companies they work for. The same study shows that one in three employees feel uncomfortable expressing their ideas; $20 \%$ were not receiving necessary feedback from their managers; $95 \%$ of employees wanted to be recognized and rewarded for their contributions in the company; $30 \%$ of employees don't feel their organizations are innovating; $68 \%$ promote their companies as a good place to work. Study also shows that in the Asia Pacific Region, Singapore ranked low when it talked about employee engagement; the top three being Thailand, Vietnam and Indonesia and the bottom three are Malaysia, S. Korea and Japan. The research concluded that Singaporean employees need three factors at work, to wit: achievement, camaraderie and fair treatment.

\section{E. Employee Engagement and Gender}

A research study conducted by Boston College showed that gender was found to be one of the overall drivers of employee engagement (Tshilongamulenzhe\&Takawira, 2015). The above-mentioned research established that "work engagement is gendered so that it is easier for men to be engaged than women." This supposition was also confirmed by the study of Human Capital Institute as cited by Thome (2013) which established that men are more engaged than women in the workplace. The following reasons why men are more engaged than women (Bailey, et. al., 2015) are the following:

1. Men and their characteristics are regarded as more useful than that of women;

2. The masculine characteristics are rewarded;

3. Men can easily experience psychological safety and be engaged than women in the workplace.

\section{METHODOLOGY}

\section{A. Research Design}

This study aimed at finding out the engagement levels of foreign teachers in Saint Nicholas School in Phitsanulok, Northern Thailand. Specifically, the study focused on the following variables identified by Gallup as cited by Reilly (2014) that greatly contributed to employee engagements of foreign teacher, namely: basic needs, management support, belongingness and opportunities for growth. Gender was also given attention as one of the important elements that affects teacher engagement. 


\section{B. Respondents}

The researcher conducted the study among foreign teachers at Saint Nicholas School in Phitsanulok. There were 11 female and 10 male totaling to 21 respondents.

\section{Instrument}

The instrument was adopted from the questions designed by Gallup namely the Gallup Q12 Employee Engagement Survey (Nishioka, (2017). This questionnaire was extensively used by businesses and educational institutions all over the world to measure employee engagement levels with the end in mind of yielding productive, committed and happy employees (Gallup Employee Engagement Center, (n.d.). The questionnaire is composed of three parts, namely: Part 1 - Respondents' Profile

Part2 - Gallup Q12 Employee Engagement Survey Questionnaire which composed of four parts, to wit: basic needs, management support, belongingness and opportunities for growth. A 6-point scale was used to rate each question which clearly highlight strengths and opportunities. The 6-point scale descriptions are as follows:

6 Extremely Yes

5 Yes

4 Somewhat Yes

3 Somewhat No

2 No

1 Extremely No

Table 1 -work engagement levels of foreign teachers for level 1 - basic needs

\begin{tabular}{|l|l|c|c|c|}
\hline \multirow{2}{*}{$\begin{array}{c}\text { Level } \\
\text { Basic Needs }\end{array}$} & Question & Mean & Interpretatio & SD \\
\cline { 2 - 5 } & 1 & 1. Do you know what is expected of you at work? & 5.43 & $\begin{array}{c}\text { Extremely } \\
\text { Yes }\end{array}$ \\
\cline { 2 - 5 } & $\begin{array}{l}\text { 2. Do you have the materials and equipment to do your } \\
\text { work right? }\end{array}$ & 4.90 & Yes \\
\hline
\end{tabular}

For Level 1, the researcher observed that the mean answer for question 1 is 5.43, meaning that the respondents really know what they are expected to do at work. Moreover, with a mean of 4.90, the respondents also have the necessary materials and equipment for their work.

Table 2 - work engagement levels of foreign teachers for level 2 - management support

\begin{tabular}{|c|c|c|c|c|}
\hline \multirow{5}{*}{$\begin{array}{l}\text { Level } \\
\text { Management } \\
\text { Support }\end{array}$} & Question & Mean & Interpretation & $\mathrm{SD}$ \\
\hline & $\begin{array}{l}\text { 3. At work, do you have the } \\
\text { opportunity to do what you do best } \\
\text { every day? }\end{array}$ & 4.81 & Yes & 0.56 \\
\hline & $\begin{array}{l}\text { 4. In the last seven days, have you } \\
\text { received recognition or praise for } \\
\text { doing good work? }\end{array}$ & 4.76 & Yes & 0.69 \\
\hline & $\begin{array}{l}5 . \quad \text { Does your supervisor, or } \\
\text { someone at work, seem to care about } \\
\text { you as a person? }\end{array}$ & 4.90 & Yes & 0.39 \\
\hline & $\begin{array}{l}\text { 6. Is there someone at work who } \\
\text { encourages your development? }\end{array}$ & 4.81 & Yes & 0.96 \\
\hline
\end{tabular}

For questions $3,4,5$, and 6 , the mean values are 4.81, 4.76, 4.90, and 4.81, respectively. It means that the respondents were given opportunity to do their best and receive recognition or praise for their work. In addition to that, the respondents feel 
secure on their workplace, since someone cares for them as a person and encourages them to seek continuous development.

Table 3 - work engagement levels of foreign teachers for level 3 - belongingness

\begin{tabular}{|c|c|c|c|c|}
\hline & Question & Mean & Interpretation \\
\cline { 2 - 4 } Level 3 Belongingness & $\begin{array}{l}\text { 7. At work, do your opinions seem } \\
\text { to count? }\end{array}$ & $\begin{array}{l}\text { Your company/school make you feel } \\
\text { your job is important? }\end{array}$ & 4.52 & Somewhat Yes \\
\cline { 2 - 5 } & $\begin{array}{l}\text { 9. Are your associates/colleagues } \\
\text { committed to doing quality work? }\end{array}$ & 4.57 & Yes \\
\cline { 2 - 5 } & $\begin{array}{l}\text { 10. Do you have a best friend at } \\
\text { work? }\end{array}$ & Yes & 0.46 \\
\hline
\end{tabular}

For Level 3, table 3 shows that all but number 8 have the same interpretation, but still the answers are all positive. It turns out that the respondents feel that their opinions count, their colleagues seems to do quality work, and they have a best friend at their workplace. On the other hand, the respondents somewhat feel that their job is important, based on the mission/purpose of their company/school.

Finally, for Level 4, table 4 shows that all the entries have the same answer. It turns out that the respondents have talked with somebody about their progress and they have actually had opportunities to learn and grow.

Table 4 - opportunities for growth

\begin{tabular}{|c|c|c|c|c|}
\hline \multirow{2}{*}{$\begin{array}{c}\text { Level 4 Opportunities for } \\
\text { Growth }\end{array}$} & Mean & Interpretation \\
\cline { 2 - 4 } & $\begin{array}{c}\text { 11. In the last six months, } \\
\text { has someone at work talked } \\
\text { to you about your progress? }\end{array}$ & 5.14 & Yes \\
\cline { 2 - 4 } & $\begin{array}{l}\text { 12. In the last year, have } \\
\text { you had opportunities to } \\
\text { learn and grow? }\end{array}$ & 5.00 & Yes & 0.33 \\
\hline
\end{tabular}

Table 5 - consolidated result of levels of work engagement

\begin{tabular}{|l|c|}
\hline Factors & Mean \\
\hline Level 1 - Basic Needs & 5.17 \\
\hline Level 2- Management Support & 4.82 \\
\hline Level 3- Belongingness & 4.50 \\
\hline Level 4-Opportunities for Growth & 5.07 \\
\hline
\end{tabular}

In general, Level 1 got the highest engagement level, with a mean score of 5.17. It means that the respondents seem to enjoy their work because their company/school gives them their basic needs. Other than that, the respondents are generally having positive work engagement.

Q 2: What engagement factors are the male foreign teachers most engaged in?

Table 6 - male work engagement levels

\begin{tabular}{|l|c|}
\hline Factors & Mean \\
\hline Level 1 - Basic Needs & 5.25 \\
\hline Level 2 - Management Support & 4.65 \\
\hline
\end{tabular}




\begin{tabular}{|l|c|}
\hline Level 3 - Belongingness & 4.40 \\
\hline Level 4 - Opportunities for Growth & 5.05 \\
\hline
\end{tabular}

Based on the table, the male foreign teachers are engaged mostly on their basic needs. As a teacher, they should have the necessary materials for their discussion.

Table 7 - female work engagement levels
Q 3: What engagement factors are the female foreign teachers most engaged in?

\begin{tabular}{l} 
Factors \\
\hline Level 1 - Basic Needs \\
Level 2 - Management Support \\
Level 3 - Belongingness \\
Level 4 - Opportunities for Growth \\
Similar to the male foreign teachers, female foreign teachers \\
tend to be more focused on their basic needs. In addition, they \\
are also focusing on the opportunities for growth. This means \\
that female teachers do not only focus on their basic needs, \\
but also pursues growth on their workplace. \\
Q 4: What engagement factors are the male foreign teachers \\
least engaged in? \\
Based on the table on RQ 2, male foreign teachers feel that \\
they are not alone on their workplace, but still, Level 3 got the \\
lowest mean score. It means that although they do not want to \\
feel that they are unimportant to their colleagues, the \\
respondents seem to focus more on more important matters.
\end{tabular}

Table 8 - significant difference of work engagement levels of male and female teachers.

\begin{tabular}{|l|l|l|l|}
\hline \multicolumn{2}{|l|}{ Factors } & t-value & Significance \\
\hline \multirow{4}{*}{ LEVEL 1 } & Q 01 & -.513 & .614 \\
\cline { 2 - 4 } & Q 02 & -.584 & .566 \\
\hline \multirow{5}{*}{ LEVEL 2 } & Q 03 & 1.237 & .231 \\
\cline { 2 - 4 } & Q 04 & 1.411 & .174 \\
\cline { 2 - 4 } & Q 05 & .032 & .974 \\
\cline { 2 - 4 } & Q 06 & .930 & .364 \\
\hline \multirow{5}{*}{ LEVEL 3 } & Q 07 & 1.060 & .302 \\
\cline { 2 - 4 } & Q 08 & 2.003 & .060 \\
\cline { 2 - 4 } & Q 09 & -.163 & .872 \\
\cline { 2 - 4 } & Q 10 & .058 & .955 \\
\hline \multirow{2}{*}{ LEVEL 4 } & Q 11 & -1.212 & .240 \\
\cline { 2 - 4 } & Q 12 & 1.416 & .173 \\
\hline
\end{tabular}

The table shows that there is no significant difference in the work engagement among male and female foreign teachers across all factors and questions. This means that gender doesn't affect the work engagement of a teacher/employee.

\section{CONCLUSIONS AND RECOMMENDATIONS}

The study found out thatboth male and female work engagement levels were generally high and gender doesn't
Q 5: What engagement factors are the female foreign teachers least engaged in?

Similar to the male foreign teachers, female foreign teachers want to focus more on other things aside from thinking of belongingness to their company/school. Moreover, both male and female respondents want to focus more on their job and needs as a teacher.

Q 6: Is there any significant difference in the work engagement among male and female foreign teachers in Phitsanulok? affect the work engagement among foreign teachers in Saint Nicholas School, Phitsanulok.

The researcher would like to recommend the following in order to maintain the high engagement levels of teachers in schools:

1. Provide basic needs of teachers such as attractive salary package, just benefits, conducive work environment, etc; 
2. Design effective opportunities for growth such as periodic professional development programs, holistic intervention programs for moral, physical and psychological needs of teachers;

3. Show strong management support for academic and non-academic endeavors of teachers and students;

4. Devise operational interpersonal relationship programs like $R \& R$, recollections and retreats, open forum, monthly birthday celebrations, Employee Appreciation Day, etc.

\section{REFERENCES}

[1] Banihani, M, Lewis, P, and Syed, J. (2013), "Is work engagement gendered?", Gender in Management: An International Journal, Vol. 28, No. 7, pp. 400 - 423. 8. Barkhuizen, W. (2014), "Spice up employee engagement in your office", Management Dynamics, pp. 4-5 (November).

[2] Bailey C, Madden A, Alfes K, Fletcher L, Robinson D, Holmes J, (2015, June). Evaluating the evidence onemployee engagement and its potential benefits to NHS staff: a narrative synthesis of theliterature. Health ServDeliv Res 2015; 3(26). DOI: $10.3310 / \mathrm{hsdr} 03260$

[3] Gallup Employee Engagement Center. (n.d.). Retrieved March 11, 2020, from https://q12.gallup.com/public/en-us/Features

[4] Nishioka, R. (2017, October 5). Use the Gallup Q12 Questions to Manage Your Manager. Retrieved March 11, 2020, from https://www.business2community.com/human-resources/use-gallup-q 12-questions-manage-manager-01926550

[5] Thome, E. (2017, January 30). Employee Engagement: Why Is Gender (Still) A Factor? Retrieved March 5, 2020, from https://talentculture.com/employee-engagement-why-is-gender-still-afactor/

[6] Tshilongamulenzhe, M. \&Takawira, N. (2015). Examining the gender influence on employees' work engagement within a South African University. Risk Governance and Control: Financial Markets and Institutions. 5. 110-119, from 10.22495/rgcv5i2c1art5.

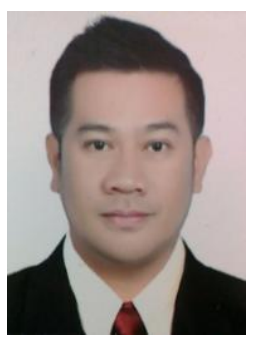

Ronnie Torres, OMI is currently the Deputy Director of Saint Nicholas School in Phitsanulok, North of Thailand. He is a PhD Candidate and a graduate of MA in Pastoral Ministry; MA in Education major in English and Literature; BS Theology; AB Philosophy; and BS Secretarial Administration major in secretarial education. His research interests involve human resources, ethics and morality. 